\title{
Introduction
}

\section{Ins and Outs of Separatist War}

On the night of March 25, 1971, thousands of soldiers fanned out in Dhaka and other population centers of East Pakistan, the Pakistan military intent on crushing the Bengali movement for independence. Operation Searchlight targeted political leaders, students and radicals, unarmed civilians, even women and children. Soldiers attacked universities, raided newspaper offices, and wiped out entire villages. The Pakistan military's brutal repression, designed to keep East Pakistan within the bounds of the state, accomplished precisely the opposite: a grinding nine-month civil war, resulting in the deaths of many hundreds of thousands and the birth of an independent Bangladesh. ${ }^{1}$

Just two decades later, the world witnessed a very different divorce. Slovaks in what was then Czechoslovakia began clamoring for their own state, making their preferences clear in the 1992 election. Rather than use force, however, Czech politicians and leaders politely stepped aside in the face of Slovak nationalism and negotiated the secession of the Slovak Republic without a single shot being fired. ${ }^{2}$ In contrast to the extremely high levels of violence that characterize other separatist disputes, the dissolution of Czechoslovakia was almost bizarrely peaceful.

A puzzle then presents itself: why do some states resist independenceseeking movements with repression and violence-such as Sri Lanka in its northern Tamil areas and the Ottoman Empire in Armenia-while others respond with a metaphorical shrug of the shoulders and territorial concessions, seen in the Velvet Divorce of Czechoslovakia or the separation of Norway from Sweden early in the twentieth century? Moreover, why do we see variation within states as they calibrate their responses to various independence movements? For instance, why did the Indian state treat Kashmiri separatism more harshly than secessionism in Assam in the 1980s and 1990s, and why was it more violent in Punjab after 1987 than before? 
Why deal with some secessionists with the proverbial pen, others with the all-too-literal gun? In this book, I explain states' particular strategieschosen from a menu of options, ranging from negotiations and concessions, to policing and counterinsurgency, to large-scale violence and repressionwhen dealing with separatist movements.

I argue that the external security implications of a secessionist movement determine a state's strategy, guiding whether, and how much, it coerces separatists. The choice of coercion turns on the state's fear of future war, or lack thereof. Future war worries states because secession negatively alters the balance of power, with respect to both the secessionist ethnic group and existing state rivals. The ethnic group poses a greater threat to the state after secession than before because of the military, economic, demographic, and legal benefits of statehood. Meanwhile, existing states pose a greater threat after the redrawing of a state's borders because its loss of territory and population axiomatically mean it possesses less material power than before. These large and rapid power shifts set up a commitment problem: why risk graver threats tomorrow if the state is stronger today? As such, if a state fears future war, it will adopt coercion against the secessionists to foreclose the possibility of such threats. Conversely, sanguinity about the future is necessary for the state to consider peaceful concessions, including the granting of full independence. Whether a state coerces separatists, then, depends on whether it believes it will face future war, which in turn depends on two factors. With respect to the seceded ethnic group, the state concludes future war is likely if there is a deep identity division between the group and the central state. With respect to the existing rivals, the state assesses future war as likely if its regional neighborhood has a militarized history, marked by conflict and war.

If the state chooses coercion based on either of these "trip wires," the extent of third-party support for the secessionists determines how much violence the state employs, for both materialist and emotional reasons. Materially, external backing makes the rebel movement stronger, increasing the amount of violence required to defeat it. Emotionally, deep alliances with rivals of the state can lead to pathological violence, fueled by a sense of betrayal. External security, then, is key to understanding both whether, and how much, states coerce secessionists.

\section{Why We Need a Theory of Secessionist Conflict}

Most wars today are civil wars, and most civil wars are fought between central governments, on the one hand, and ethno-nationalist groups seeking autonomy or independence, on the other. In the last seven decades, there have been about twice as many nationalist civil wars (ninety-five) as 
interstate wars of any kind (forty-six), ${ }^{3}$ leading to the conclusion that such wars are the "chief source of violence in the world today." ${ }^{4}$ Indeed, between 1946 and 2005, the world saw, on average, over twenty-five such conflicts in any given year. ${ }^{5}$

Even within the general category of civil wars, separatist conflicts are deadliest. ${ }^{6}$ The primary distinction between so-called ideological and secessionist civil wars is that the latter feature an ethnic and territorial component, in which borders are contested. ${ }^{7}$ The central question fought over in ideological wars is: which groups are in power? The corresponding question in separatist wars is: which groups are in the state? Peacefully resolving either is a challenging task, but on average, separatist wars tend to last longer. ${ }^{8}$ Additionally, they occur slightly more frequently than ideological civil wars. ${ }^{9}$ The bottom line is that if scholars and analysts are interested in explaining conflict in international politics, they could do worse than begin with secessionist violence, "one of the central puzzles surrounding civil war," 10 or indeed war more generally.

War, it goes without saying, is a complex and multifaceted phenomenon, and explaining its trajectory over time is a herculean task. The challenge in studying war-indeed in social science more generally-lies in drawing general lessons about a phenomenon that hinges on a series of contingent factors. We make grand pronouncements about the lessons of World War II, but would we understand the pitfalls of aggressive expansionism differently had Hitler simply obeyed his generals and advanced straight to Moscow upon reaching the Dvina and Dnieper rivers, rather than toward Ukraine and Leningrad? Alternatively, would we remember the Great War as exemplifying trench warfare had the Germans wheeled east rather than west of Paris in the early stages of the Schlieffen Plan's execution, exposing their flank to the French? The overarching point, one that luminaries from Sun Tzu to Clausewitz have noted, is that war is a brutally complex process, and theorizing about its dynamics is devilishly difficult. Consequently, one needs a simplifying approach, and the one I adopt in this book is to focus on the critical junctures in the process that is war. ${ }^{11}$ Specifically, I pay special attention to how states respond to separatists at what I term "secessionist moments," when a group's secessionism is made explicit to the central state.

I define secessionism as demands by an ethno-nationalist group for either independence from, or significant regional autonomy within, a modern nation-state. ${ }^{12}$ There are two main reasons we would want to cast our definitional net to catch both "full" secessionist as well as regional autonomist movements. First, movements often vacillate between demands for statehood and autonomy based on short-term tactical considerations. ${ }^{13}$ Second, gaining significant autonomy, such as when a region has its own police and military forces, or independent economic policy-making power, often proves a very long step toward establishing statehood. ${ }^{14}$ Thus state 
decision makers-and scholars analyzing them—should treat demands for independence as essentially synonymous with those for significant autonomy.

A secessionist moment is when an ethno-nationalist group's demands are expressed in no uncertain terms to the central government. Such secessionist moments can take the form, among others, of an ethnic or regionalist political party winning a landslide election victory; a massive rally, riot, or demonstration that compels fence-sitters to choose sides in favor of those demanding independence; or an assassination, murder, or kidnapping that unites the opposition. A secessionist moment, at bottom, is when an ethnonationalist group's demands have crystallized into a widely held collective desire for significantly greater autonomy or independence. It forces the incumbent government to make a decision: how do we respond to this?

It is that decision which I investigate. The reason for this focus is that states themselves determine to a large extent-and certainly to a larger extent than the ethno-nationalists - whether a secessionist struggle will be peaceful, violent, or genocidal. About half (75/163, or 46 percent) of all secessionist movements lead to full-blown war. ${ }^{15}$ In other situations, states use lighter forms of coercion. In yet others, they may not use force at all. The range of actions available to states, owing to their institutional, legal, political, and military power, is simply wider than it is for nonstate actors. This is not to say that the preferences, constraints, tactics, and goals of the secessionist group are unimportant. ${ }^{16}$ Rather, I claim simply that how states respond initially at secessionist moments has great import for how those secessionist movements proceed. If they offer negotiations or concessions, there is little likelihood that the secessionists will escalate to more violence. If they respond with violence, odds are the secessionists will too, setting a spiral in motion. Even the category of "violence" is much too wide. States can use largely discriminate or largely indiscriminate tactics; they can use strategies that rely more on the military than the police or vice versa, each with its own set of implications for a conflict's trajectory. Thus we can learn a great deal about the outbreak and development of ethnonationalist civil wars by understanding states' decision-making at these secessionist moments. And, in turn, we can learn a great deal about states' decision-making by examining the external security implications of the secessionist movement.

My argument that the international system exerts a tremendous pull on state strategy against secessionists rests on two core insights in international relations (IR). First, the international environment has systematic effects on states' domestic politics. ${ }^{17}$ Second, and more directly, states mired in security rivalries worry a great deal about shifts in the balance of power. ${ }^{18}$ Indeed, as I emphasize throughout this book, the mere potential for shifts in the future balance of power can cause war. ${ }^{19}$ 
This theory builds on the explosion in research on civil war in the last two decades in IR, comparative politics, and security studies. Generally speaking, civil war researchers exploring violence break down into three camps: those who focus on structural conditions, others who concentrate on rebels and insurgents, and yet others who examine the state, as I do. Each type of scholarship is crucial to understand the whole picture of violence in civil wars.

Structural arguments point to factors correlated with the incidence and dynamics of civil war. These studies identify the broad patterns of internal conflict, explaining which types of states and territories are most likely to experience such wars and why actors' incentives in such contexts often encourage them to use violence. ${ }^{20}$ Scholars of rebels and insurgents, meanwhile, study why their use of violence may vary across time and space. For instance, some have argued that civil wars that feature opportunist fighters, motivated by the promise of a share of natural resources or significant state sponsorship, are more likely to see indiscriminate violence than those that are fought by more ideologically committed fighters, since the latter are better placed to practice internal discipline. ${ }^{21}$ Others argue that the resources on offer are not singularly determinative; rather, the precise social-organizational context in which insurgents enjoy resource endowments determines their use of violence. ${ }^{22}$ Still others examine how movements, organizations, and insurgencies can splinter and how such internal splits can generate violence. ${ }^{23}$ Notably, even these scholars that focus on the rebel side of the civil war equation underline the importance of the state, particularly in the most gruesome conflicts. ${ }^{24}$ For their part, scholars who focus on states offer different explanations for the circumstances under which states become intensely violent. Some point to state desperation and a lack of viable alternatives as factors that push states to victimize large numbers of people. ${ }^{25}$ Others argue that states "see" certain spaces and peoples in particular ways that render some more prone to violence than others. ${ }^{26}$ Yet others investigate the role democratic institutions play in curtailing repression against citizens. ${ }^{27}$

Within this broad area of civil war research, several scholars have attempted to theorize state response to secessionism, my central explanatory task in this book. This research, however, overwhelmingly focuses on domestic factors. One dominant school of thought explains the reaction(s) of states to ethno-nationalists with reference to the concepts of reputation, signaling, and deterrence. ${ }^{28}$ Scholars from this school argue that by fighting hard against the ethno-nationalist group du jour, and therefore acquiring "hard" reputations, governments can deter future would-be nationalists from even trying to secede. ${ }^{29}$ This theory expects ethnically heterogeneous states to fight harder than relatively homogenous-especially binationalstates because the former's relative diversity implies a greater number of potential secessionists that need to be deterred. 
While logical and a substantial first step in the systematic study of secessionist conflict, the reputation argument has three main flaws. First, the evidence in its favor is mixed; some large-n statistical results are more supportive of this argument than others. ${ }^{30}$ Second, the reputation argument underpredicts violence in binational states. While the absence of "other" groups for the state to deter would lead theorists to expect exceedingly peaceful measures by the state, as seen in Canada's or Czechoslovakia's confrontations with secessionist minorities, ${ }^{31}$ Sri Lanka and Israel are binational too. Third and most important, it struggles to explain internal variation in state response to secessionism because its independent variable - states' demographic profile-does not change but the outcomepeace versus violence-does. This is problematic because the vast majority $(136 / 163$, or 83 percent) of secessionist movements took place in a state experiencing multiple movements. Furthermore, of those 33 "multiple movement" states, 19 (58 percent) sometimes used violence and sometimes did not, leaving aside even finer distinctions within the category of "violence." Internal variation is a big slice of the separatist violence pie. ${ }^{32}$

More recent research has argued that the internal structure of states affects how they respond to self-determination movements. One view is that the number of "veto factions" within a state-those factions that can veto policy change-constrains which states can offer concessions to movements and which cannot. Because states are "consensus-building," concessions can occur only when all relevant factions agree on their advisability. Large numbers of veto players are likely to result in internal deadlock, leaving the state unable to offer concessions. But, interestingly, even low numbers of veto factions make states less likely to offer concessions. The argument forwarded is that a state with few veto factions is a less credible bargainer in the eyes of self-determination movements, and as a result, it foresees that such groups will not place any trust in concessions it offers. Therefore, it does not make any concessions in the first place..$^{33}$ Thus there is a proverbial sweet spot of veto factions-about five-where concessions from states are most likely. ${ }^{34}$ In other situations, either the state cannot offer concessions, or believing that ethnic groups will not accept them as credible chooses not to do so. ${ }^{35}$

Though the focus on the internal politics and factionalization of states and movements is valuable and a significant advance in conflict studies, this analysis too ignores the role of geopolitics. More important, while the internal structures of self-determination groups assuredly are important determinants of the state opting for concessions or war, ${ }^{36}$ the relationship between states' internal structures and their strategies seems murkier, both empirically and theoretically. Empirically, even scholars favoring this argument admit to the more limited effects of the internal structures of states relative to that of groups and concede that their qualitative evidence says 
little about the role of veto factions in contributing to state strategies. ${ }^{37}$ This lack of evidence on the causal mechanisms connecting veto factions to outcomes is made more troubling by the logical problems in the theory connecting the two. While one can easily accept why large numbers of veto factions, and the attendant potential for internal deadlock, may make concessions more difficult, ${ }^{38}$ it is difficult to see why a low number of veto factions is similarly damaging to the prospect of concessions. ${ }^{39}$ Why would a unitary or centralized state hesitate to make an offer of concessions simply because a group might deem such an offer untrustworthy, a suspicion based on nothing more than the number of veto factions within the state ${ }^{40}$ What would be the cost of having such an offer rejected? Is it even reasonable to expect state leaders to make such fine-tuned calculations, whereby they choose to forego offers of concessions they would have otherwise made because they believe the movement, itself deciding between whether the state has three or five or eight veto factions, would deem such an offer incredible if the number falls below a certain threshold? As such, the claim that there exists a curvilinear relationship between the number of veto factions within a state and the likelihood that it offers concessions requires further substantiation. ${ }^{41}$

Finally, some scholars marry an emphasis on internal institutions to the reputation logic, tracing how the nature of a state's administrative boundaries determines its response to separatists. The claim is that states are liable to allow peaceful secession to regions that represent a "unique" administrative type. By contrast, territories that share administrative status with others could instigate a domino effect were they granted concessions; such secessionist regions thus see resistance from states. ${ }^{42}$ While an important contribution to the debate on separatist violence, this argument's treatment of the breakup of colonial empires and modern nation-states as one and the same is problematic. Colonial powers may have split their empires into various units, such that France administered Algeria differently than West Africa, but countries in the modern era are more uniform in how they divide territory, with just one major administrative line creating either provinces, regions, states, or cantons. Since states do not generally create differentiated administrative boundaries as empires did, this argument is less applicable to modern separatist conflict than the independence struggles of native nationalists against colonial rule. ${ }^{43}$

While this literature makes valuable and telling contributions, then, it leaves out a huge factor: the external security ramifications of secession, and how they condition a state's behavior. More generally, recent civil war research has tended to ignore geopolitics, focusing instead on explaining the dynamics of violence in specific local contexts. ${ }^{44}$ Such inattention is a mistake. Because security is the most important international goal of 
states ${ }^{45}$ we miss a great deal by ignoring the bigger picture. Secession dramatically alters the international balance of power facing the rump state in very negative ways, which cannot help but color state responses to separatists. Establishing a new border would imbue a possibly threatening ethnic group with the considerable material, social, and institutional power that accompanies statehood. ${ }^{46}$ As evinced by the Ethiopia-Eritrea and RussiaGeorgia wars in the last two decades, along with grave tension between neighbors such as Kosovo and Serbia or Sudan and South Sudan or Russia and Ukraine, war between a rump and a seceded state remains a distinct possibility. Additionally, losing substantial territory and population at a stroke considerably weakens a state relative to existing state rivals, who can act opportunistically against the weakened state. Rather than face these (threats of) war against strengthened rivals, the state is better off using coercion. Even the calibration of how much coercion to employ depends on an external factor, third-party support, since such backing makes rebels stronger on the battlefield and decision-makers and security forces more emotional. This typology of coercion-from policing to militarization to collective repression-brings nuance to the view held by most scholars that states merely choose between peaceful concessions and violent denials when dealing with separatists.

Incorporating the external environment in theoretical accounts of state strategy to secessionism also seems reasonable given the ample attention it has received in related inquiries, especially in recent research on nationalism, ethnic conflict, and the creation and destruction of state boundaries. ${ }^{47}$ For instance, scholars have found that external conditions are crucial in explaining decisions to assimilate, accommodate, or exclude particular nations or ethnic groups from the political-social fabric of the state. ${ }^{48}$ Additionally, research has shown that ethnic cleansing is especially likely when rival states, in an effort to bring about changes to the territorial status quo, form an alliance with an ethnic group on the territory they seek to win. ${ }^{49}$ More generally, the international environment often determines how long and bloody a civil war will be..$^{50}$ This is especially true when it comes to the involvement of third parties, who upon deciding to intervene in a secessionist conflict, ${ }^{51}$ irrevocably change the dynamics of such wars. Under such circumstances, the civil war becomes "nested" under an unstable regional or systemic conflict, making it more intractable..$^{52}$ Civil wars that feature third parties are longer, more intense, and less prone to negotiated settlements. ${ }^{53}$ In part, this is because third-party support for rebels can affect the calculations of the ethno-nationalist groups and their leaders. Insurgents will become emboldened and radicalized if they perceive that, due to the interventions of outside powers, the balance of power between them and the central governments will shift. Scholars have shown that even the mere prospect of support can lead such groups to adopt more extreme demands. ${ }^{54}$ Finally, the external environment also 
plays a significant role in the (re)drawing of borders on the map, ${ }^{55}$ the precise outcome secessionists hope to accomplish. Secessionists' ultimate success in forming states often depends on international relations, ${ }^{56}$ and such states do not become fully sovereign unless they are recognized by the international community as such-recognition which is contingent on great power politics. ${ }^{57}$

The importance of international factors allows us to gain greater insights on separatist conflicts both past and present. Consider the Israel-Palestine dispute (chapter 5), a diplomatic and security problem festering for decades. My argument sheds light on how a "liberal" democracy such as Israel can go to the lengths it does to deny statehood to the Palestinians. The hostility of its Arab state neighbors historically, combined with an essentializing of Palestinians that subsumes them under a larger "Arab" identity, means that Israel's decision makers forestall Palestinian statehood, using as much coercion as necessary to do so. Similarly underlining the significance of geopolitical forces, Sudan and Ethiopia supported violent separatism on each other's territory for decades, while the long-running Nagorno-Karabakh dispute is essentially an internal conflict in Azerbaijan wrapped within its interstate rivalry with Armenia.

In addition to clarifying such disputes, this book makes several empirical contributions. First, unlike domestic-variable arguments, the theory I present here is adept at explaining internal variation in states' treatment of ethnic nationalists. Why might a state such as Pakistan treat Bengalis differently from Baloch in their respective quests for independence, merely two years apart? Why would India employ more brutal, indiscriminate tactics in Kashmir than Assam despite facing secessionist movements in both states at the same time? My theory can also account for variation over time: why the Ottoman Empire would treat Armenian nationalists differently in 1915 than in 1908, or why Sikh separatism in Punjab provoked more violence after 1987 than in 1985. Such internal variation is of enormous consequence because most secessionist movements ( 83 percent) take place in states experiencing more than one such movement, and in turn, most of these "multiple movement" states treat certain groups differently from others. Arguments that center on, say, ethnic heterogeneity struggle to explain why a state with an unchanging demographic profile may behave differently at different times against different groups.

Second, the ability to explain cases of extremely violent separatist conflicts is a strength of my theory. Most of the thirty-three cases of "intense" separatist warfare involve some external component. ${ }^{58}$ In Africa, both the Nigeria-Biafra and Ethiopia-Eritrea conflicts featured high levels of support from regional and global powers. ${ }^{59}$ The Sudan-South Sudan war had strong external reverberations not just because of Ethiopia's intervention, but also because the seceded state and its former host are on the verge of outright war. The bloodiest separatist conflicts in South Asia-Indian 
Kashmir, northern Sri Lanka, and East Pakistan-had significant geopolitical implications, as we shall see later in this book. Long, deadly fights between the Kurds and various states in the Middle East, but especially Iraq, Iran, and Turkey, have been marked by fears of external wrangling. My argument attempts to make sense of why separatist conflicts that have an external angle to them are prone to extremely high levels of violence.

Third, the role of geopolitics in civil conflict is not especially well captured by existing research, much of it characterized by large-n statistical studies based on a few popular datasets. For instance, the widely used PRIO Armed Conflict dataset considers civil wars "internationalized" only when a state fashions its troops in support of domestic rebels; it is impossible given these data to examine the effects of more limited support, such as financial or military aid. I bring a finer-grained and more nuanced understanding of how external support can affect states' decision-making.

Focusing on external security does not just benefit academic research of separatist war but can also serve as a useful guiding principle for policymakers interested in curtailing the death and destruction that such conflicts usually leave in their wake. Understanding the factors that cause some governments to address secessionist demands on the battlefield, as opposed to the negotiating table, is crucial to peace building. Such an understanding would allow interested parties to pursue strategies designed to keep the peace between ethnic groups in a state, and promote stability more generally. Although the international community is often reluctant to interfere in civil conflicts because of concerns about political and legal sovereignty, ${ }^{60}$ my research suggests that the roots of fighting within borders often lie outside those borders. This implies that the international community can play a significant role in these conflicts by allaying the fears of states facing separatist movements and providing them with reassurance of their security.

For instance, the international community can make the shift in the balance of power attendant on secessionism more palatable to the rump state by providing defensive guarantees and pledging protection from its military rivals in the future. The international community could tie the promise of security guarantees to good behavior in its dealings with the minority, as part of an explicit quid pro quo. For instance, if the United States had promised Pakistan military aid and a security partnership in 1971, in return for a more measured and less violent policy against the Bengalis, we might never have witnessed the genocide. A contemporary example of such a policy would be American military support of Israel being made contingent on more concessions to the Palestinian independence movement, while providing explicit security guarantees to Israel against state threats, including those from Palestine. A further implication of my study is that as a secessionist conflict brews in a particular country, the international community 
must restrain the state's geopolitical rivals. These rivals must make explicit and credible guarantees that they will not join forces with the secessionists in any meaningful way, either today or in the near future. This will aid in placating the state and make it less fearful of "encirclement," which often drives the most vicious of responses. A present-day example of such an idealistic policy would be to pressure both India and Pakistan to cease material support for Baloch and Kashmiri separatists respectively.

The research presented here, then, is highly relevant to policymakers who wish to curtail civil violence. In a nutshell, I suggest that the international community must place front and center the motivations of central governments repressing secessionists. It also implies that, as with most conflicts, the time to contain the conflict is before it actually erupts: by guaranteeing the security of the state in the future, the international community can protect the victims of the state in the present. The overarching lesson is: third-party involvement would be most useful in separatist conflicts if it is (a) early, before hostilities have taken place; (b) made contingent, such that exhortations for better treatment of ethnic minorities go hand in hand with security (and possibly other) cooperation with the host state, and (c) aimed at dissuading support for the movement by global or regional rivals of the host state.

\section{Research Design}

In this book, I deal with secessionist movements in the twentieth century. I consider any movement as falling within the scope of my argument if it sought to escape the control of a larger state by establishing a state of its own or an autonomous region. There were 163 such movements after 1946, a start date chosen because most datasets on political violence have little reliability before that date. I ignore decolonization movements, which I believe should not be conflated with secessionist movements in modern nation-states. Any anticolonial movement that was geographically cut off from its target by a substantial body of water, ${ }^{61}$ as was the case for African and Asian movements against British, French, Portuguese, and Dutch rule, was not considered. With geographic contiguity in mind, I include in the dataset the dissolution of the Soviet Union, which some scholars consider an "empire," 62 and conduct a detailed examination of the Ottoman Empire's treatment of its Armenian minority (chapter 5).

\section{METHODOLOGY}

As social scientists have discussed, case-study research has many virtues, including greater confidence in the theory's internal validity, a greater 
attentiveness to causal mechanisms, a deeper and more detailed accounting of empirical variation, and appropriateness for questions for which data and information are incommensurable across a population of $\operatorname{cases}^{63}$ assuredly a characteristic of separatist conflicts, some of which are significantly more opaque than others. It is for these reasons that my primary method of empirical research is historical. Much of the literature on civil war and secessionist violence employs quantitative methods and large-n datasets. Such research is not especially adept at showing causal mechanisms at work. As mine is a theory of decision-making, it is imperative to get the causal mechanism right, and this can be done only with close historical examination of cases of secessionism.

I employ the "most-similar" method, by which a researcher studies a pair (or more) of cases which are similar in all respects except the variables of interest. ${ }^{64}$ In general, this method results in greater confidence in the theory if, within the pairwise comparison, there is wide variation in the independent and dependent variables and all other dimensions are highly similar. ${ }^{65}$ At times, scholars can divide a single longitudinal case into two subcases, a technique known as "before-after research design," as long as care is taken to ensure only one significant variable changes at the moment that divides the two periods. ${ }^{66}$ Combining this most similar method with processtracing allows us greater confidence in the theory ${ }^{67}$ Process tracing is a method by which the researcher zooms in on the causal mechanisms linking a hypothesized independent variable to an outcome. Causal mechanisms are the "meat" of any theoretical argument; they are the processes and intervening variables through which an explanatory variable exerts its influence over the outcome in question. ${ }^{68}$ Though there are valid varieties of process-tracing, the one I employ in this book is that of "analytic explanation," whereby historical narratives are couched in explicit theoretical terms. ${ }^{69}$ Throughout these narratives, I emphasize both where my argument is consistent with the evidence as well as where it is contradicted by it, pointing to the importance of elements outside my theoretical framework in a number of cases. After all, no one social scientific theory can explain all relevant aspects of major phenomena or events, and it is incumbent on careful researchers to be attentive to the importance of other variables and contingencies.

\section{CASE SELECTION}

I choose to focus primarily on states experiencing more than one secessionist movement, for two main reasons. The first is methodological: choosing multiple cases falling within one state, especially in narrowly circumscribed periods, gives us the best chance of fulfilling the conditions of "most-similar" research design outlined above, since structural factors such as state wealth, institutional structure, and geography are likely 
to be common across both movements. The second is substantive: a vast majority of secessionist movements take place in "multiple movement" states. An argument that can explain variation in response to secessionism in one state would be considered, all else equal, more powerful than those that suffer at the hands of the internal variation problem.

Choosing individual cases to study from my larger universe of 163 movements after 1946, as well notable pre-World War II movements, requires careful consideration. How is a particular case situated in the more general population? Is this case being used to infer a theory or test one? Is it establishing a theory's range or its antecedent conditions? ${ }^{70}$

To test my theory, I focus on South Asia. Specifically, I examine Pakistan's reactions to Bengali and Baloch demands for independence in the 1970s in chapter 3, and India's responses in Kashmir, Punjab, and Assam in the 1980s and 1990s in chapter 4 . Theories of secessionist violence have mostly been built on the experience of the Balkans and the Caucasus. ${ }^{71}$ South Asia, generally speaking, has escaped the attention of scholars dealing with secessionism. This is a strange omission given each major state in South Asia-India, Pakistan, Bangladesh, and Sri Lanka-has experienced secessionism, and in India and Pakistan's cases, multiple movements across both space and time. One should endeavor to choose "typical" or "representative" cases, ${ }^{72}$ and given that both South Asian neighbors are ethnically heterogeneous developing countries that have experienced multiple movements, they fit the bill. Furthermore, methodologists encourage cases with within-case diversity, encompassing the full range of values of the independent and dependent variables. ${ }^{73}$ South Asia displays this variation in my independent variable amply; certain separatist conflicts have an extremely relevant geopolitical component (Kashmir, East Pakistan), others less so (Balochistan, Punjab), and still others even less (Assam). As far as the dependent variable of state strategy is concerned, South Asia sees a wide range of state behavior, ${ }^{74}$ sometimes within the same conflict. Finally, by circumscribing my investigation in one region in one era-each of the conflicts studied occurred between 1971 and 1991-I hold structural conditions such as levels of wealth, state development and capacity, institutional structure, and demography broadly constant, leading to a more rigorous identification of why states choose the policies they do against separatists.

Later in the book, I expand the case selection to include vastly different time periods, geographic locations, and types of state. This empirical section is devoted to establishing the argument's explanatory range. The wider the theory's applicability across space, time, and context, the more confident we can be in its mechanisms.

I begin in chapter 5 with variation across time in the Ottoman treatment of its Armenian population between 1908 and 1915, when the Young Turk regime went from accommodating the Armenians in 1908 to seeking their wholesale forcible removal from Ottoman territory during World War I, 
leading to genocide. As scholars have pointed out, "extreme" cases, or those where either or both of the independent and dependent variable are present in large quantities, have significant methodological value. It is precisely because these observations lie far from the median that they prove so instructive. ${ }^{75}$ The Ottoman case displays the largest variation in the dependent variable in this book, with state strategy veering from the most peaceful, "negotiations and concessions," to the most violent, "collective repression." Second, because the Ottoman case was not one of a modern nation-state, as are most of the cases I consider in this book, but an empire in the midst of dissolution, its inclusion increases the breadth of the sample being tested.

Chapter 6 continues the theme of gauging the theory's explanatory power in vastly different situations so that we can be confident that the argument "travels." I begin with the interaction between Israel and Palestinian nationalists, focusing especially on the first intifada, for two main reasons. First, this dispute allows a direct comparison of my argument with its primary competitors, centering on reputation and institutions. As a binational state, one that is a wealthy, liberal democracy no less, Israel has no "other" ethnic communities than the Palestinians, and thus should be expected to not have any concerns about establishing a "tough" reputation to deter future independence movements. At the time of the Madrid and Oslo talks in the aftermath of the first intifada, Israel was led by a center-left government with the support of Arab parties in the Knesset. Consequently it should have had little need to resort to violence against Palestinians. My argument would predict the opposite, given Israel's security concerns with the prospect of an independent Palestine. That is, Israel is a "most-likely" case my competitors-a case which is predicted to result in a certain outcome, but does not $^{76}$-made more significant by the fact that my theory makes the opposite, and correct, prediction in this case.

I then investigate the Velvet Divorce separating Czechs and Slovaks at the end of the Cold War and the dissolution of the Norway-Sweden union in 1905. Generally, social scientists are "concerned not only with cases where something 'happened,' but also with cases where something did not." 77 It is important that any theory of separatist conflict address one or both of these cases, since they, as two of a handful of completely peaceful secessions of the twentieth century, occupy the extreme ends of the spectrum, just as the Armenian and Bengali genocides do. Choosing extreme cases only because they are extreme may strike some as violating the social science tenet to "not choose on the dependent variable." However, qualitative scholars encourage choosing such extreme cases, as long as they are accompanied by cases that are more representative, because it allows for maximizing "variance on the dimension of interest."78 Without an 
understanding of what factors led to relatively rare outcomes in these cases, it would be difficult to identify the necessary and sufficient conditions for peaceful separatism more generally. ${ }^{79}$

Finally, I investigate the U.S. Civil War, even though it technically lies outside the data universe of my argument: it neither took place in the twentieth century, nor was it, strictly speaking, a case of an ethnic group seeking independence. Nevertheless, the very fact that it does not fit the profile of the type of secessionist struggle I study makes it a useful litmus test: if my argument can account for elements of a dispute that lies outside its original scope conditions, we can gain even greater confidence in its explanatory power.

The overall sample, then, consists of three states that experienced separatism before World War II (the United States, Ottoman Empire, and Sweden) and four after (Pakistan, India, Czechoslovakia, and Israel). The cases feature each of authoritarian, democratic, monarchic, and imperial governance. Some are highly centralized states, others highly federalized. The geographic scope is similarly varied: I cover North America, Northern Europe, Eastern Europe, the Middle East, and South Asia. Most crucially, the sample contains each of the four major strategies I discuss, ranging from negotiations to limited war to genocide, leaving me with a great deal of material to test my argument.

\section{Table 1 Explaining case selection}

\begin{tabular}{|l|l|l|}
\hline Goal & Case & Methodological value \\
\hline \multirow{4}{*}{ Testing the theory } & Pakistan & $\begin{array}{l}\text { Variation in IV and DV across space } \\
\text { (Bengal vs. Balochistan) }\end{array}$ \\
\cline { 2 - 3 } & India & $\begin{array}{l}\text { Variation in IV and DV across space } \\
\text { (Kashmir vs. Assam vs. Punjab) and across } \\
\text { time (Punjab 1985 vs. post-1987) }\end{array}$ \\
\hline \multirow{3}{*}{$\begin{array}{l}\text { Establishing explanatory } \\
\text { range of the theory }\end{array}$} & Ottoman Empire & $\begin{array}{l}\text { Large variation in IV and DV across time } \\
\text { (Armenians in 1908 vs. 1914-15) }\end{array}$ \\
\cline { 2 - 3 } & Czechoslovakia & Extreme case \\
\cline { 2 - 3 } & Israel-Palestine & $\begin{array}{l}\text { "Most-likely" case for reputation } \\
\text { argument }\end{array}$ \\
\cline { 2 - 3 } & U.S-Confederacy & Outside original scope conditions \\
\hline
\end{tabular}


DATA

The empirical material for this book is drawn from various sources, including more than 110 semistructured interviews I conducted in person with current and former political, diplomatic, and security officials; journalists and analysts; insurgents; and scholars and academics (or, for those interviewees in Europe, the Middle East, or South Asia, over the telephone or Skype). Additionally, I draw on tens of thousands of pages of diplomatic archives, primarily from American and British sources. ${ }^{80}$ Daily newspaper archives, especially but not only of the Assam Tribune, Chandigarh Tribune, Dawn, Kashmir Times, and Times of India, also proved invaluable. ${ }^{81}$ In addition to these sources, I used other primary and secondary material, such as memoirs, interviews to the press, internal government memoranda concerning secessionist conflicts, and detailed case studies in other disciplines such as history and sociology, and biographies. 